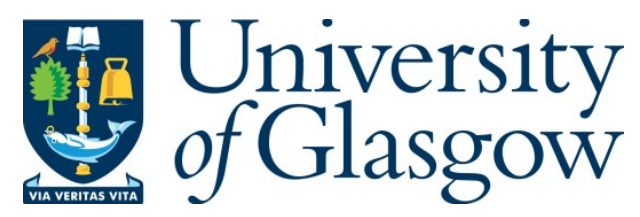

Cerretano, V. (2020) Autarky, market creation and innovation: Snia Viscosa and Saici, 1933-1970. Business History. (Early Online Publication)

(doi: 10.1080/00076791.2020.1750599)

This is the Author Accepted Manuscript.

There may be differences between this version and the published version. You are advised to consult the publisher's version if you wish to cite from it.

http://eprints.gla.ac.uk/212885/

Deposited on: 27 March 2020

Enlighten - Research publications by members of the University of Glasgow http://eprints.gla.ac.uk 


\section{Autarky, market creation and innovation: Snia Viscosa and SAICI, 1933-1970}

Valerio Cerretano

This article reviews the history of Snia Viscosa and its moves into the production of staple fibres and cellulose (as well as allied chemicals) between 1933 and 1970. This is a neglected but crucial episode in the business as well as industrial history of Italy and feeds into a variety of debates, most notably the nature and impact of autarky. This article confirms that autarky stimulated innovation via scale economies rather than a demand-induced effect. It also seems to show that, while redistributing resources also towards giant firms not directly involved in the war effort, autarky led to an overexpansion of technologies which were overtaken by wholly synthetic fibres, in the production of which Snia Viscosa lagged behind. Another strength of the article lies in its extensive sources.

Starting its main line of business in 1921 from a series of plants located in the environs of Turin and Milan, Snia Viscosa swiftly developed into the largest man-made fibres firm and the largest corporation by capital in Italy. The man-made fibres industry was a high-tech, capital intensive sector. Until the late 1930s and before the advent of nylon, it only made one fibre, namely rayon, which was a cellulosic fibre marketed in the form of yarn and staple fibres (i.e. yarn cut at standard length). Given the company's size and importance for the Italian economy, it comes as little surprise that Snia Viscosa has been the focus of much scholarly attention (for an updated literature see Cerretano, 2018; sketchy but useful are also Spadoni, 2003 and Castronovo-Falchero, 2008). While documenting its expansion, historians have shown that Snia Viscosa was an interesting case of multinational Italian firm. They also have established that Snia Viscosa came to be acquired in 1927 by its direct competitors, notably the British firm Courtaulds and the German company Vereinigten Glanzstoff Fabriken (Coleman, II, 1969b; Jones, 1986; Cerretano, 2018). Finally, they have demonstrated that the British and German interests kept close connections with Snia Viscosa even during the 1930s and the Second

\footnotetext{
${ }^{1}$ I would like to thank Gianluigi Scarpa and Taddeo Molino Lova of Mediobanca; Matilde Capaldo of the historical archives of IMI - Intesanpaolo at Acilia (Rome); Annalisa Bertani and Eleonora Cortese from the Archivio del Lavoro of Sesto San Giovanni (Milan). Andrew Cumbers, Gian Carlo Falco, Anthony Gloyne and Robert McMaster commented on previous drafts of the article. They all deserve a word of gratitude. My special thanks also go to Maria Adorante for her precious support over the years.
} 
World War (Coleman, II, 1969b; Jones, 1986; Cerretano, 2018).

Despite the geopolitical strains, the collapsing global economy and the persistent difficulties in remitting dividends, Snia Viscosa and its European partners exchanged patents and know-how throughout the 1930s (Coleman, II, 1969b; Jones, 1986; Cerretano, 2018).

The moves of Snia Viscosa into the cellulose and electrochemical business beginning from the 1930s have by contrast received comparatively scant attention. After a period of rapid growth, by 1929 the company experienced a steep decline followed by renewed expansion. An explanation for that renewed expansion can be found in the creation of a domestic market and in the launch of rayon staple fibres, which in turn required heavy investment in the making of the main raw material, e.g. cellulose. To ensure continuity in the supply of that raw material, in 1937 Snia Viscosa launched the Società Agricola Industriale Cellulosa Italiana (hereinafter Saici) in the Friuli region, in the North East of the country. Saici was meant to make cellulose from non-woody sources, namely reeds, but later branched out into chemical and electricity production. Saici, moreover, was one of the most grandiose industrial projects carried out in Fascist Italy, and unsurprisingly the regime took much pride in it.

Snia Viscosa was a first mover in staple fibres, as well as in the making of cellulose for rayon, and faced tremendous financial and technological challenges when starting their production. The history of that company offers valuable insights into how the state reduced the risks associated with new investment. Mazzucato recently restated, in the wake of Polanyi (1944), the notion that markets are historical constructs which were heavily shaped by 'state actions' (Mazzucato, 2018, p.15, p.36). In the 1930s, growth rested on the domestic market, the phenomenal expansion of which represented the most important development in the rayon industry from the 1900 s to the 1980 s. Through import prohibition, export subsidies and scientific research, the state was instrumental in that process.

That history also broadens our knowledge of the impact of economic self-sufficiency (autarky) on the corporate Italian economy 
(Grifone, 1971; Petri, 2002; Zamagni, 1998). As Petri pointed out, the neo-mercantilist policy framework put in place in the 1930 s persisted until the early 1960s (Petri, 2002, pp.197-9; p.310). In relation to economic self-sufficiency, the judgment of historians seems to have swung dramatically since the immediate post-war period, from one of blame (Rossi, 1966; Saraceno, 1977; Ministero per la Costituente, 1947) to another of substantial justification (Zamagni,1998, p.13; Petri,2002, p.194). Over the past two decades, the argument has often been made that the search for surrogates favoured the launch of innovations. These failed to bear fruits immediately but proved of some significance in the post-war context (Zamagni,1998, p.13; Petri, 2002, p.194).

Although with some qualifications, the case presented here gives much substance to the latter claim. Autarky set the conditions for the launch of staples fibres, which remained the most important innovation in this industry until the 1950s, and for the start of a domestic industry of cellulose. The question as to how (and the extent to which) autarky may have contributed to inventive activity thus feeds into the broader debate about the impact of demand on innovation (Schoomkler, 1962 and 1966; Mowery and Rosemberg, 1979; Dosi, 1982). There is no evidence here about demand-induced innovations, as basic technology in staple fibres and cellulose-making predated autarky. What we see is rather a Verdoorn-Kaldorian effect whereby growing demand brought about growing scale economies and, with it, greater expertise (Kaldor, 1967, p.15, p.19). Learning by doing, while going often unpatented, proved crucial in this industry which remained in between the chemical and textile industries.

Important as they are in supporting that view, the findings presented here also seem to caution against over generalisations (as the one made by Zamagni, 1998, p.13). One conclusion here is that autarky stimulated an overspecialisation of the firm in staple fibres technology which after 1950 were overtaken by wholly synthetic fibres. In addition, this article confirms that scarcity of foreign currency remained the independent variable of an industrial policy equation in which industry was the dependent variable 
(Hirschman,1987, pp.245-6; Petri, 2002). Snia Viscosa was picked up as an industrial champion because it exported massively, while contributing to an import reduction of natural fibres. One inference here is that autarky redistributed resources also towards big firms not directly involved with the war effort. This is an important acquisition in relation to current debate. This has assumed, although often only implicitly, that autarky had effects exclusively on armament industries (an example of this posture is Zamagni, 1998).

The originality of this article must be found in its unusually extensive sources. It is largely based on primary information which is scattered in numerous private and public archives in Europe and in the USA, among which the IMI archives in Rome, the CGIL archives and the Mediobanca headquarters in Milan stand out.

The article begins by describing autarky and the role that Snia Viscosa had in it, emphasising the importance of the man-made fibres industry in ensuring a steady flow of much-needed foreign currency. The second section considers how the state smoothed the creation of a domestic rayon market. One point here is that that was one of the most important developments for the Italian man-made fibres industry since its early founding. The next sections consider how autarky fostered the launch of staple fibres and the firm's strategy of large-scale economies. Section five and six by contrast examine the launch of Saici in the cellulose industry and its development after 1945. That part of the article corroborates the argument made by Petri that the neomercantilism of the 1930s remained long in place after the Second World War.

\section{Shaping autarky}

We already mentioned that the creation of a domestic Italian market, the renewed expansion of Snia Viscosa and the diffusion of staple fibres constituted the salient aspects of the history of this industry in the 1930s. Prior however to looking at those developments, we need to turn our attention to autarky and to the role of Snia Viscosa in shaping it. 
There was no agreed definition for autarky. Historians seem to concede that total insulation was not necessarily an aim of autarky or economic self-sufficiency and that different interpretations to be given to it co-existed, a point which was emphasised also in an oftquoted document of the time (Gagliardi,2007, p.128; Petri, 2002, pp.134-5; Ministry of Corporations, November 1937). As foreign currency reserves collapsed, late in 1934 the regime introduced exchange controls. Autarky or economic self-sufficiency was however officially inaugurated only in March $23^{\text {rd }} 1936$ when Mussolini gave a speech to the second national assembly of corporations, i.e. the gilds or organisations representing both industrialists and workers, which had replaced parliamentary democracy in Italy (Gagliardi, 2007,p.127). The Ministry of Corporations pointed out that economic self-sufficiency, while not aimed at rearmament alone, could also be pursued in normal times (Ministry of Corporations, November 1937). Most important, autarky had nothing to do with economic planning or the impairment of private initiative. While Mussolini emphasised a radical departure from the liberal principles in international trade, the Ministry of Exchanges Felice Guarneri, who was the Italian equivalent of Hjalmar Schacht, considered it a necessary evil to restore the balance of payments that deteriorated very rapidly after 1931 (Gagliardi, 2007, p.128; Petri,2 002, pp.134-5). The issue of scarce currency, more than ideology, remained central to the policy of economic self-sufficiency. Little surprise then that Italy, as Hirschman pointed out, introduced exchange controls much later than other countries of the gold block, notably Germany, which experienced massive capital outflows after September 1931 (Hirschman, 1987, p.165).

According to Petri, autarky served the purpose of reallocating resources to heavy and capital -intensive industries (Petri, 2002, pp.134-5). To this process of reallocation, exchange controls and the heavy involvement of firms in decision-making proved central (Petri, 2002, pp.134-5). The history of Snia Viscosa seems to confirm that, more than rearmament, balance of payments considerations 
influenced industrial policy and the picking up of industrial champions.

The top management of Snia Viscosa shaped autarkic plans to the firm's full advantage. Much of their bargaining power rested on the consideration that the rayon industry exported massively, thus guaranteeing an influx of foreign currency. From the early 1920s, rayon represented one of the country's top exports (Federico et al, 2009, p.26, Table 1.6). In 1934, e.g. in the most critical year for the country's balance of payments, rayon exports guaranteed a surplus of about 400 million lire (Guarneri, 1988, p.699).

The leading figures of Snia Viscosa, notably Franco Marinotti, had a big say in the definition of autarky in textiles. On paper, production targets were set up by the so-called 'corporazioni' (Gagliardi, 2007). Although representing all vested interests, these organisations were controlled by industrialists. The textile guild was no exception. In that context, it was an easy game for Marinotti to convince policy-makers that independence in textiles could be reached by increasing the production of stable fibres and by encouraging cotton and wool spinners to use them in greater quantity (Marinotti, 1937, p.275)

The posture, and sharp business opportunism of, Marinotti found justification, of course, in the technological supremacy of Snia Viscosa in staple fibres technology. The output of staple fibres could increase very rapidly, while in terms of urgency, the issue of textile production in the autarkic plans came only after that of energy production (the value of imports of cotton and wool was almost the same as that of coal) (Maiocchi, 2003,p.76). The textile guild recognised that in 1930-4 home-made natural and non-natural fibres covered only about 20 percent of domestic consumption (Ministry of Corporations, November 1937). It also foresaw that in 1940 textile producers would produce only 85 thousand metric tons of textile fibres against a need of 210 thousand, of which 50 and 13 thousand were to be covered with rayon staple fibres and rayon yarn respectively (Ministry of Corporations, November 1937). 
However, a growth in rayon output implied a parallel expansion of cellulose consumption. This was the main raw material of both rayon and explosives (i.e. nitrocellulose powder) and was entirely imported from Scandinavia. Growth in rayon output would put then strains on cellulose supplies, worsening the trade balance (Maiocchi, 2003, p.81, p.172). A report on cellulose to Mussolini in October 1936, highlighted a deficit of 70 thousand metric tons of cellulose, equivalent to a capital outflow of 200 million lire (Report on autarky, October 1936). This fact urged policy-maker, rayon and paper firms to begin a domestic production of wood-pulp (Maiocchi, 2003, p.81, p.172).

Scarcity of wood-pulp resulted from cyclical phenomena (i.e. reduction of wood supply), but also from booming new demands. As shown in Table 1, the consumption of the rayon industry grew much more rapidly than total consumption (almost six times against slightly more than twice) between 1926 and 1938, coming to account for about 50 percent of overall consumption in 1938. In that context, a debate about alternative sources of cellulose that would be able to dampen supply cycles in this business took place in Italy but also in other industrial countries. This debate, moreover, continued after the Second World War. In October 1930, the War Office in Britain, for example, began to investigate the possibility of producing cellulose within the country (Kerr, 17 October 1930). The Korean war in 1950-3 brought once more about new price hikes, reinforcing the view that shortages of cellulose occurred from time to time (Extracts from Collier's minutes, $1^{\text {st }}$ January 1952; Grant, 1959, pp.339-40) . A major conference on non woody sources of cellulose met in London in 1952 (Grant, 1959, pp.339-40). In a press release in December 1952, the newly-established Food and Agriculture Organisation pointed out that 'a pulp industry based on tropical and sub-tropical woods and agricultural discards is a feasible commercial venture...such an industry could more than offset the rising world demand for paper and newsprint' (FAO Press release, 15 December 1952) 
The discussion in Italy after 1918 followed similar lines but took a turn after 1934 (Maiocchi, 2003, p.81). One solution was seen in the cultivation and exploitation of poplar, which grew much more rapidly than spruce, and in the use of decidual plants, such as reeds, as well as agricultural discards, such as straw, which more than poplar could meet the immediate needs for cellulose (Acerbo, 1934; Ministry of Corporations, November 1937). One optimistic assumption was that 40 metric tons of reeds and straw per hectare would produce 10 tons of cellulose, and that as a result the country would produce 1,500 tons of cellulose by 1944 , half of which to go in the production of rayon, thus making the country totally independent from Scandinavian wood-pulp by 1946 (Ministry of Corporations, November 1937).

\section{State, autarky and market creation}

Taken in a long-term perspective, the creation of a domestic market can be considered the single most important development in the evolution of the man-made fibres industry in Italy. The growth of this industry had rested initially on massive exports. Although remaining significant after 1929-31 (Italy was the main source of rayon exports throughout the 1930s), they however became less important relative to domestic consumption. The relative importance of exports and of the domestic market in the evolution of this trade is shown in Table 2, from which it also emerges that a boom in domestic consumption began in 1934 .

What accounted for this development? In the next section, we will see that its technological premises must be found in the mass production of staple fibres, in the production of which the Italian firm, along with the German firm IG Farben, was a pioneer. In this section, by contrast, we will consider the crucial support from the state in the creation of a vast domestic market.

Support came not so much in the form of restrictions in rayon imports, which remained almost non-existent throughout the time period under consideration. Nor did it come, as with Nazi Germany, in the form of a direct financial involvement in the setting up of 
staple fibres plants (Scherner,2008). Although he is silent about the Nazi wood-pulp programme and about the origins as well as evolution of staple fibres technology in Germany, German historian Scherner has shown that the Nazi government, essentially via state guarantees, gave a major push to the production of staple fibres in Germany (Scherner, 2008, p.881). Direct state involvement, along with a greater availability of cellulose, might explain why Germany increased staple fibre output much more than Japan and Italy (see Table 3 for a comparison). With hindsight, state involvement probably reduced an overcommitment of private undertakings in the production of staple fibres.

State support in Italy rather came through, first, reductions in cotton imports; second, through the compulsory use of rayon in cotton spinning; third, through the special treatment given to rayon in international trade negotiations; last but not least, through scientific research conducted under the aegis of certain state agencies (from Comitato delle Ricerche, the newly-created Ente Nazionale per la Carta e la Cellulosa and the Istituto per la Ricostruzione Industriale).

Of these measures, the reduction of cotton imports and the compulsory use of rayon were the most significant. Drawing largely on Federico et alia (2011, p.20, Table 1.4), Table 4 shows that imports of natural fibres (a major entry for the country's trade deficit) declined after 1935. It also confirms that a reduction (by quantity) of imports began in earnest in 1934, while the relative growth in 1937-8 was likely a consequence of the piling up of stocks and growing re-exports of cotton manufactures.

The largest outlet for rayon (staple fibres in particular) was cotton spinning which accounted for about 60 percent of the whole market after 1934-5 (Mauro, 1944, pp.41-2). According to the Istituto Cotoniero Italiano, staple fibres accounted for one third of all the raw materials employed by cotton spinners after 1934, while in absolute terms the consumption of staple fibres by cotton spinners grew from 14 to more than 60 thousand metric tons between 1935 and 1939 (Mauro, 1944,pp.41-2). In cotton weaving, by contrast, 
rayon consumption increased from 8.5 to 31.7 thousand metric tons between 1934-8 according to the Ministry of Corporations (Ministry of corporations to the director of the Bank of Italy, 10 March 1938). Import restrictions began in February 1935 when the government fixed the imports of the first three months at 50 percent of the previous year and then at 35 percent for the remainder of the year and finally at 15 percent in 1936 (Mauro, 1944, pp.41-2). From April 1936 , the government introduced a much stricter discipline on cotton imports via the Istituto Cotoniero (Mauro, 1944, pp.41-2). The main purpose was distribute cotton mostly to exporters with the aim to generate a larger inflow of foreign currency at the expense of domestic consumption. The gap of textile raw materials was to be filled with national textiles, notably rayon. The Ministry of Currency and Exchanges estimated that the needs of the cotton industry were (spinners in particular) at 1,200 metric tons of cotton and mixed fibres in 1936 (Ministry of Corporations, November 1937).

The first law obliging cotton spinners to purchase rayon made its appearance in March 1936 (RDL 9 March 1936). Until 1936, cotton spinners remained very sceptical about the use of staple fibres but the government and Snia Viscosa did not deploy coercive methods to force them to employ rayon (Snia Viscosa, Minutes of Board of Directors, 2 March 1936). In 1939 however ad hoc measures obliged spinners to use at least 20 percent of rayon in textile goods sold into the domestic market (RDL 6 February 1939 n 315 and DM 20 April 1939 n. 1057).

In order to increase rayon consumption, Snia Viscosa purchased several spinning and weaving firms (SA Manifattura Maglierie Milano, la SA Filatura di Voghera, la SA Industrie Tessili Inverigo e la SA Torciture di Vittorio Veneto). It also made, with cotton spinners, informal agreements which the Ministry of Corporations labelled of 'self-discipline' (Ministry of corporations to the director of the Bank of Italy, 10 March 1938). The Istituto Cotoniero brokered deals between Snia Viscosa and the cotton spinners. That was a cartel established in 1913 and became a state sponsored cartel in 1934. It also was the chosen government (and big 
business) instrument to increment the use of staple fibres in the cotton industry.

The Istituto Cotoniero had a monopoly over cotton sales, especially abroad; it was compulsory for cotton spinners and was informally controlled by the Under ministry and later Ministry of Exchanges and Currency. The Istituto Cotoniero regulated sales prices at home and abroad while distributing the imported raw cotton among the affiliates of the cartel, paying attention to exporters. The Istituto Cotoniero also made all purchases of national fibres, most notably rayon, on behalf of the cartel's members (Grifone, 1971, p.135). It was instrumental in pushing the sale of rayon among spinners and helped Snia Viscosa to secure large contracts with cotton spinners (ICl directive N 21, 4 maggio 1937). In July 1937, for example, the Istituto Cotoniero obliged all firms under its influence to use in mixed yarns at least 15 percent of staple fibres (ICl directive N 33, July 1937).

The role of the government proved equally crucial also when it came to foreign trade. In 1934, the whole industry ensured a surplus of 400 million lire accounting, according to one source, to about 5 percent in terms of value of total Italian exports between 1928 and 1938 (Imperial Economic Committee, 1936-9). To Guarneri (1988, p.699), behind state support lay also a desire to stimulate exports of high-tech industries which in Italy were still relatively few. The support of the government was particularly welcome when between 1934-6 it forestalled attempts made by the German rayon industry and the Nazi government to ban Italian rayon from Germany (Minutes of Ministries Committee, 12 December 1935). Exports of rayon accounted for about 14 percent in terms of value of total Italian exports into Germany.

Last but not least, the state provided scientific and technological aid, an area which is recognised as being crucial in shaping markets (Mazzucato, 2018, pp.1-20). As will be seen below, Saici produced according to a process (Italian Patent 227313, March 1936; British Patent, 496312, November 1938) which was developed by scientist and businessman Francesco Giordani 
(http://www.treccani.it/enciclopedia/francesco-giordani (DizionarioBiografico/ /) and the newly established Ente Nazionale per la Carta e Cellulosa, which was a state-owned agency charged from 1935 with the development of wood-pulp from non-woody and alternative sources. The Ente Nazionale developed the rhizomes of reeds which provided to Snia Viscosa in 1937 (Ostuni, 2015-6, p. 130-43; Ostuni, 2018). Snia Viscosa also benefitted from the research work made for the selection of poplars and their cultivation on a large scale, which followed the indications of scientists Francesco Carlo Palazzo and Carlo Levi. They insisted on the use of poplar as an alternative source of cellulose. Their ideas, moreover, were reflected in the law decree of 18 May 1936 (n.1838) for the cultivation of poplar (Ostuni, 2005-6, p. 130-43).

\section{State, autarky and innovation: the case of staple fibres}

So much for state and market creation. But what about the impact of autarky on inventive activity? And what about its effects on the strategy of the firm? Here and in the next section we will attempt these questions.

There is no evidence suggesting that autarky had a demand-pull effect on staple fibres technology. Its impact was more in terms of risk reduction associated with the commercial launch of the new product; of scale economies; and of growing experience. Greater production resulted in learning by doing improvements which went unpatented and often unrecorded.

Also, when autarky began, the foundations of staple fibres technology had already been laid. The first patents were taken out in the early days of the industry, and Snia Viscosa acquired them while entering into this line of business in the early 1920s. Between 1907 and 1912, patents were taken by French technologists Augustin Pellerin and Paul Girard, and by British chemist Mitchell. (H.Möis Avram, The rayon industry (London, 1930 edn, pp.124-7, US Tariff Commission,1944, pp.402-3; Coleman, 1969b, p.). During the First World War, the production of staple fibres experienced some expansion under the lead of Glanzstoff and Koeln Rottweil (by 1926 
part of IG Farben). After the First World War these fibres continued to be in some demand in the wool industry (Avram, 1930 edn, pp.124-7; US Tariff Commission, 1944, pp.402-3). They were cheaper than yarn and could be mixed in spinning with natural fibres. 'Attention is being given to staple fibres', reported the Economist in April 1926, 'it has undoubtedly great potentialities.', (The Economist, 17 April 1926).

The contribution of Snia Viscosa in this field came from the mechanical side. This was a cutting machine patented under the name of Antonio Beria in Italy, Britain and USA in 1927-8 (BP 289,028; Hegan, 1951, pp.403-5; Coleman, II,1969, pp.268-70; Cerretano, 2012). The Beria machine developed Pellerin's idea of collecting fibres from a spinning jet with a greater number of holes (namely 1,200 against 50 or 70 in the case of spinning jets deployed in yarn spinning) in the form of a thick tow or bundle, which went first through a funnel and then a number of blades. That machine was much faster than the ones in use at IG Farben and Glanzstoff (Cerretano, 2012). Snia Viscosa sold them to Courtaulds, Glanzstoff and the American Viscose Corporation (Cerretano, 2012).

The history of Snia Viscosa seems to confirm Petri's point whereby under autarky giant Italian firms made investment knowing that this would pay back once costs would be reduced as a result of growing scale economies (Petri, 2002, p.135). The condition for that to happen however was that technology was essentially sound. The fact that autarky may have fostered markets for products of unclear validity seems to be demonstrated by the episode of 'Lanital.' Lanital was an artificial protein fibre obtained by mixing casein with certain acids and other chemical compounds that Snia Viscosa launched in 1935. Lanital came to account for as much as 4.5 percent of Snia Viscosa's output in the early years of the Second World War (see Table 5).

Lanital made its appearance while also other firms, such as DuPont, ICl and IG Farben were developing protein fibres (Coleman, Courtaulds, III,1980, p.68). As with staple fibres, artificial protein fibres technologies predated autarky. Snia Viscosa acquired a process 
developed by chemist Antonio Ferretti, who improved patents that British chemist Miller and German scientist Todtenhapt took in the 1900s. Ferretti claimed to have improved methods of purification of the casein, but many questioned his claim. In a report to a Courtaulds' representative in Snia Viscosa, a technologist emphasised that 'as soon as normal times will come back in Italy, this casein wool proposition will be forgotten again...this casein wool does not show appreciable advantages above ordinary wool.' (Maters to John Hanbury-Williams, 24 January 1936'). After initial interest in the Ferretti process, DuPont and American Viscose Corporation rejected its acquisition, casting doubt on the patent position and commercial success of the product in the USA (Salvage, Cable to John Hanbury-Williams, 9 June 1937). By contrast, Courtaulds acquired the rights to that patent in Britain and in Canada and marketed the Lanital there as Fibrolan. The production of that protein fibre continued to experience some growth in Italy (as Merinova) and Britain until the immediate post-war period but came to be replaced by acrylic fibres in the early 1950s. As additional evidence of its doubtful validity, Nazi Germany and Japan did not foster casein fibres because their basic raw material, casein, could also be used as food.

\section{Autarky and corporate strategy: staple fibres}

In relation to the impact of autarky on the strategy of Snia Viscosa, one conclusion here is that a large domestic market and staple fibres offered the company the chance of resuming a strategy of large-scale economies that had characterised the early development of the firm. In this section we will see that that strategy, while beginning in the early 1920s, was interrupted in 19267 and then resumed in 1931.

Staple fibres came to account for as much or more than 60 percent of Snia Viscosa's output after 1935. Tables $\mathbf{3}$ and $\mathbf{4}$ show that the company was globally one of their largest producers, while Italy, along with Germany and Japan, were their main producing countries. 
The countries of the Axis stimulated the production of staple fibres because they were viable substitutes to natural fibres and allowed savings of much needed foreign currency (through the reduction of cotton imports). As Coleman noted, a boom in their production also took place, however, in Britain and in the USA, where there was a relative abundance of natural fibres (Coleman, II, 1969, p.270).

As already mentioned, Snia Viscosa secured the early knowhow for staple fibres when taking the 'Societè Italienne de la Viscose' from Paul Girard in 1920-1. In 1923, the management of the firm envisaged their mass-production as 'Sniafil' and, after 1931, as 'Sniafiocco' (Coleman, II, pp.184-6, pp.268-70). For their launch the firm envisioned grandiose initiatives in 1923-4. The most important of these was the construction of Abbadia di Stura (nearby Turin) and the launch of foreign subsidiaries, notably the 'British Snia Viscosa' (Cerretano, 2004 and 2018). Abbadia di Stura was the largest rayon plant in Europe. The planned output capacity of staple fibres in that plant was 50 out of 60 thousand kilos per day of the firm's total output capacity (this also was more than the daily output of the whole company) in 1925 (Cerretano,2004 and 2018). As emphasised by Cerretano (2018), if cheap Italian labour was clearly an advantage for the firm, Snia Viscosa lacked the experience to make good yarns until the early 1930s, a major obstacle in the way of a strategy of large-scale economies. Staple fibres overcame the problem of a large production of poor-quality rayon, thus dovetailing nicely with the strategy of the firm.

The stabilisation crisis in 1925-6 and then the collapse of global trade from 1931 put brakes on that strategy. While facing growing uncertainty in foreign outlets, the management of the firm began toying with the idea of developing a domestic market. Among other things, a large domestic market allowed high prices (i.e. above competition levels) at home and price transfers, with which undercut competition abroad (Cerretano, 2018). Table 3 shows that the company's output of staple fibres more than doubled between 1935 and 1939, accounting for about 70 and 8 percent of national and global production of the new fibres. Production took place mostly at 
Abbadia and at Cesano Maderno. Late in the 1930s all plants, including those acquired from Cisa group in 1939, produced staple fibres. This is shown in Table 6.

While smoothing the industrial consolidation of the firm, a strategy of large-scale economies bore its financial fruits. After almost a decade of financial instability and huge losses, the firm made huge profits paying handsome dividends after 1935, as Table 7 shows. Investments went in the expansion of works and in the purchase of materials. Particularly important was the investment in new holdings (see the entry holdings in Table 8), which grew ten times between 1935 and 1939. Even allowing for inflation which began to grow after 1936, that represented a staggering development. Investments were made downstream in spinning firms which would boost the use of staple fibres and, above all, upstream in the production of cellulose. The move into the cellulose industry will be the focus of the next sections.

\section{Autarky, innovation and firm's strategy: the launch of Saici}

The launch and early development of Saici will be the focus of what follows. As already mentioned, Snia Viscosa set up that company to secure a steady supply of raw materials. Moreover, the decision to embark upon the production of cellulose followed from expansion into staple fibres. Table $\mathbf{5}$ shows that Italy began a production of cellulose during autarky. In this section, we will seek to attempt the question as to how autarky facilitated the launch of that company and innovation in the field of cellulose- making.

The setting up of a domestic cellulose industry was per se an important development that autarky brought about. While being a capital-intensive sector, the cellulose industry was dominated by a very small number of firms and producing countries. How did autarky stimulate innovation? Once more, it is hard to establish a direct relationship, in a Schmooklerian sense, between demand and innovation. The contribution of autarky was also in this case more in terms of scale economies. 
Interesting as it was, this process should not be overestimated. One reason for this is that reeds accounted for a tiny fraction of total cellulose and their cultivation was abandoned for good in the late 1950s. Production costs remained high, as Table 9 shows. Autarky allowed economies of scale and the development of a know-how which went mostly unpatented and which bore fruits after 1945. Rather, more than solving the issue of cellulose, Saici shifted the problem of autarkic cellulose downward towards the supply of wood. Saici made cellulose mostly from wood imported from neighbouring Slovenia, which Italy occupied in 1941 (see Tables 9 and 10). Arguably the balance of payments gained some benefit from Saici's operations as wood was at any rate much cheaper in international markets than wood-pulp.

One peculiarity of Saici was that it carried out both agricultural and industrial operations on a large scale. The agricultural estate covered an area of about 5,700 hectares by 1942 (see Table 11) between the rivers Aussa and Corno as well as the Adriatic Sea, and fell within the administrative domain of San Giorgio di Nogaro, Gonars and Bagnaria Arsa, in the Friuli region (Fabbroni and Zamo, pp.11-82). The main tenements were however around Tor di Zuino, which later became Torviscosa.

That area was chosen for three reasons. First of all, it was mainly marshland (not specialised therefore in wheat cultivation) which the state had begun to reclaim after the First World War (Fabbroni and Zamo, pp.11-82 and Ministry of Corporations, Report on autarkic plans, November 1937). Snia Viscosa continued land reclamation with public support (and money) and at the noteworthy expense of 40 million current lire in 1939-40 (Saici, 1961, p. 7). A second reason should be found in the abundance of water. Saici made large use of water in several industrial and agricultural operations as well as in transportation. Water went in particular in the production of steam and electricity, needed for pulping wood and making chlorine and soda (Saici, 1949; Snia Viscosa, 1949; Saici, 1961). A third reason was the proximity to the sea and to Yugoslavia 
which became the main source of raw materials (mostly logs) for Saici.

The main purpose of the agricultural estate was of course the cultivation of reeds. Table $\mathbf{1 1}$ underestimates the area destined to reeds (the German army and then bombardments in February 1945 reduced although temporarily it considerably) but also shows the array of agricultural items that Saici produced. Agricultural production responded to the logics of rotation and the need to increase the crop of reeds. As a result of rotation, the firm embarked on the cultivation of various types of cereals, on cattle raising and the production of manure.

The industrial section comprised the processing plants for the reeds or wood's shredding; the boiling section which also included the mixing of wood with chlorine and soda; and, finally, the section where the resulting pulp was dried, pressed and then cut into foils of regular size. By 1942, probably helped by the sequestration of patents, Saici began the in-house production of chlorine and soda, but also electricity, first through a thermoelectric plant in Torviscosa and by 1949 via the hydroelectric stations along the Meduna river. Of these the plants in Meduno, Colle and Istrago were completed in 1952 and in 1957.

\section{Snia Viscosa and Saici after 1945}

One point to be stressed before drawing the conclusions is that, as Petri emphasised, the neo-mercantilist policy framework established in the 1930s persisted after 1945 (Petri, p. 197-9 and p.310), and so did the strategic considerations underlying the launch of Saici. These were, first, the protection that the state continued to offer, and, second, the strains on the supply of cellulose that continued after the end of the conflict.

As mentioned earlier, price hikes of wood-pulp had become a source of serious concern not only in Italy. In 1934 DuPont took under consideration the possibility of starting a production of cellulose (Cellulose requirements and supply, 27 February 1934). In 1940, Courtaulds drafted similar plans (Coleman, III, 1980, pp.112-3). 
The Korean war in 1950 created new shortages. Against that background, Courtaulds purchased the cellulose technologies of Snia Viscosa setting up with the Italians a joint venture in South Africa in the mid-1950s (Coleman, III, 1980,pp.112-6).

While intent upon reducing the production costs of cellulosemaking, Saici branched out into electricity and electro-chemical manufacturing in the 1950s. These developments can also be gauged from Tables 12 and 13 which show a list of products that Saici made and the productivity of Saici, as well as size in terms of labour, in relation to the mother company. As mentioned earlier, electricity was initially needed to produce steam for the treatment of wood and reeds. It remains unclear whether Snia Viscosa pursued investments in electricity to branch out in this industry or to support its core business. Electricity was also employed in the making of the chemicals and fibres (acrylic and polyamides) that the firm produced. These are shown in Tables 13 and 14. But it is tempting to conclude that electricity generation seemed to offer a safe shelter in alternative to waning tariff and similar protection from the mid1950s, a strategy that of course was jeopardised by the nationalisation of the sector in the early 1960s. However, cellulose production continued to grow and massive investment in 1956-7 were envisioned with the aim to improve Saici's old-established bisulphite process and to start a production of semi-chemical cellulose as well as paper. In the early 1960s, Saici was essentially a chemical plant while Snia Viscosa looked more like a small and incomplete chemical concern (i.e. with no footing into petrochemicals) than the rayon firm which had entered this business after the First World War.

Saici sold its output mostly to Snia Viscosa, although some of its manufactures (e.g. resins) were also sold to third parties (see Tables 14 and 15). As the Istituto Mobiliare Italiano underlined, the scale economies and productivity of Saici were mostly influenced by the demand (and output) of the mother company (IMI, Memorandum on Saici by Emilio Papasogli, $1^{\text {st }}$ July 1952). According to Mediobanca, it was the in-house production of cellulose and raw materials that 
made Snia Viscosa still profitable in the early 1970s (Ricerche \& Studi, 1970, pp.38-40).

As already mentioned, a peculiarity of the undertaking was that it also cultivated the plants that went in cellulose-making. As output expanded, by 1949, the agricultural estate embarked on the production of an additional array of agricultural products. These included meat, cheese, dairy products, wheat, animal foodstuff, fruit and fruit jams. This required investments in processing factories, stables and the like. As with the chemical or industrial section, expansion seemed to lack strategic coherence and responded to short-term accounting considerations (Saici, Board of directors, various years).

More fundamentally strategic was the choice of increasing the cultivation of poplar and eucalyptus after 1945. As already mentioned, poplar was the chosen plant of the autarky (Maiocchi,2003). Weather resistant and more productive varieties of this rapidly growing plant had been selected during the 1920s and 1930s (Maiocchi, 2003). Saici began to plant them since the company's inception but their number grew significantly from about 1956. Poplars and eucalypti replaced reeds, the production of which collapsed by 1957-8 (Saici, Board of directors, 4 June 1958) (see Table 10). In 1952 cellulose made from reeds accounted for only 11 percent of Snia Viscosa's needs, while five years later about 600 thousand poplars were planted and about 20 thousand (weighting about 10 thousand metric tons) were cut (Saici, Board of directors, 2 April 1957; IMI, Memorandum on Saici by Emilio Papasogli, $1^{\text {st }}$ July 1952). Experimentation with the eucalyptus, a rapidly growing plant originating from Australia, began during the war and in earnest from 1949. The cultivation of that plant was carried out in the warmer and drier climates of Sicily and Apulia. In 1957, there were the first crops of eucalypti, which began the main source of home-grown cellulose (Saici, Board of directors, 27 June 1957).

Important as it was, the weight of home-grown cellulose should not be overestimated. The most important source of cellulose remained wood-pulp imported from neighbouring Yugoslavia and, 
starting from 1957, from Romania and Portugal. From 1937 until 1945, as Table 8 shows, the firm made cellulose with imported wood, the main source remaining Slovenia which Italy invaded in 1941. The issue of wood supply remained very important for the viability of the firm from 1938 to about 1960 (i.e. when crops of poplar increased significantly). Along with the international prices of wood-pulp, the price and availability of hard wood was the most important variable affecting the company's performance after 1945.

Investments continued unabated from 1956 to 1964 (Official Balance sheets and the financial reports of Saici in Comit, 1946-67). In 1956, about 7.2 billion lire went in the enlargement and improvement of the chemical and cellulose plants (IMI, Deliberation of IMI's Executive Committee on Saici's demand for a mortgage loan, 17 July 1956). In 1961, 23.5 billion lire were envisaged for the new hydroelectric plants along the Meduna river (IMI, Description of Saici's patrimony, 5 December 1964). These investments were financed by the mother company through increases in capital (see Table 16). The Istituto Mobiliare Italiano (a state agency providing long-term capital set up in 1931) provided important support in 1952 (4.2 billion lire), in 1956 (2 billion lire) and in 1964 (5 billion lire) (Official balance sheets and financial reports of Saici in Comit, 194667).

\section{Conclusions}

What we have said about Snia Viscosa confirms that autarky provided, first of all, a shelter to risky investments facilitating the consolidation of new industries. The company's staple fibres and cellulose became competitive in terms of technology and costs after 1945. While however making investments in those areas, the firm increasingly lagged behind the national and international competitors in the field of wholly synthetic fibres that began to boom by the mid-1950s. According to one source, Snia Viscosa's share of the domestic output of man-made fibres decreased from 68 to 38 percent between 1955 and 1970 (Ricerche e Studi, November 1971). That outcome could be attributed to the delay with which the 
company moved into wholly synthetic fibres production. In 1970, rayon still accounted for about 58 percent of the company's output (Ricerche e Studi, November 1971).

Snia Viscosa was not a fully-fledged chemical firm with expertise in petrochemicals, a fact that complicated any move into that line of business. The company's merger in 1968 with the chemical concern Bombrini Parodi Delfino into Snia BPD sought to reduce that gap but in the early 1970s rayon still constituted the bulk of the company's output. Against that background, the fact that Snia Viscosa continued to put enormous resources in rayon staple fibres and cellulose (and its chemical and agricultural by-products) until the mid-1960s remains striking. The hypothesis is that that was a pathdependent process that autarky and neo-mercantilism had initiated. With hindsight, dismantling staple fibres and the cellulose plants, which remained still profitable in the latter half of the 1960s, would have had tremendous financial and social costs.

This episode also sheds light on the role that industrial vested interests had in defining industrial policy. One constant preoccupation of Snia Viscosa's management was to carve out monopoly rent. The state had by contrast a very lenient attitude towards big firms in this sector. Probably the dichotomy between state and business as suggested by Mazzucato (2018) is misleading in our case. Does the relationship with the government help to explain an over-expansion in staple fibres and investments in less sophisticated technologies? A comparison with other countries, particularly with Nazi Germany, could probably help to answer this question. Because of space constraints, we cannot however carry out such a comparison here. We can only note that, with hindsight, state involvement in staple fibres production in the case of Nazi Germany (Scherner, 2008) seems to have prevented the main actors into the industry (namely, Vereinigten Glanzstoff- Fabriken and the IG Farben group) from over-expanding in sectors that became less competitive just as wholly synthetic fibres began to make their appearance. 


\section{Reading list}

W. Allit, 'Report on a visit to Snia, August 1945' in V. Cerretano, 'The European rayon industry and the de-globalisation of the world economy' (PhD Thesis, Cambridge, 2003), p.206

W. Allit, 'Memorandum to the British Embassy in Rome, 9 February 1946' NA, UR 2273/287/851, FO371/58290

Giacomo Acerbo, 'Il problema della produzione nazionale di cellulosa' in Giornale di chimica industriale ed applicata, October 1934

H.M. Avram, The rayon industry (London, 1930 edn)

Banca d'Italia, L'economia italiana nel sessennio 1931-36 (2 vols, Rome, 1938), vol II

Board of Trade, Survey of Industrial Fibres, (London 1928);

Valerio Castronovo and Anna Maria Falchero, L'avventura di Franco Marinotti. Impresa, finanza e politica nella vita di un capitano d'industria (Milan, 2008)

'Cellulose requirements and supply, 27 February 1934' in DuPont Archives, Hagley Library, Wilmington (Delaware), 1771, Box 54.

Valerio Cerretano, 'European cartels, European multinationals and economic de-globalisation: insights from the rayon industry, c. 1900-1939' Business History, 54(4, 2012), pp. 594-622.

Valerio Cerretano, 'Multinational business and host countries in times of crisis: Courtaulds, Glanzstoff and Italy in the Interwar period' Economic History Review 71 (2,2018), pp.540-566

Ha-Joon Chang, Kicking away the ladder. Development strategy in historical perspective (London, 2005)

Châtillon, Minutes of the Board of Directors, Montefibre Headquarters, Milan, 6 April 1937

Donald C. Coleman, Courtaulds: an economic and social history, II: Rayon (1969b) (Cambridge, 3 vols, 1969-1980)

F.S. Collier (extracts)'s minute of the $1^{\text {st }}$ January 1952 in NA, CO 852/1193/3 
Giovanni Dosi, 'Technological paradigms and technological trajectories: a suggested interpretation of the determinants and directions of technical change, Research Policy, 11, (3,1982), pp.147-62

Flavio Fabbroni e Pierluigi Zamo', ' La SAICI di Torviscosa (1937-1948) Capitale, fascismo e movimento operaio,' in Storia contemporanea in Friuli, 3 (4, 1973), pp. 11-82

FAO, Press release, 15 December 1952 National Archives, CO 029/52

G. Federico, S.Natoli, G. Tattara, M.Vasta, I/ commercio estero italiano, Roma, 2011

Alessio Gagliardi, L'impossibile autarchia. La politica economica del fascismo e il Ministero scambi e valute (Catanzaro, 2007)

Julius Grant, Cellulose pulp and allied chemicals (NY, 1959)

Pietro Grifone, Il capitale finanziario in Italia (Torino, 1971)

Felice Guarneri, Battaglie economiche tra le due guerre (Bologna, 1988), p.699

'J.Hanbury-Williams to F. Marinotti, 17 December 1937' in V. Cerretano, 'The European rayon industry and the de-globalisation of the world economy' (PhD Thesis, Cambridge, 2003), p. 204

H.J. Hegan, 'The historical development of and the outlook for viscose fibres', Journal of Textile Institute, 42 (1951), pp. 395-410

Albert O Hirschman, Potenza nazionale e commercio estero: gli anni Trenta, I'Italia e la ricostruzione, ed. By M. De Cecco and P.F.Asso, (Bologna, 1987)

ICl directive N 214 May 1937 and Directive N33 July 1937 in [Circolare n21, 'Approvigionamento del cotone sodo per il consumo interno', 4 maggio 1937 and Circolare n 33, 'Disciplina delle vendite dei filati misti cotone e fiocco rayon', luglio 1937] in Archives of FIOM-CGIL, Milan [Archivio del Lavoro, Milano, Fondo Raitano, Faldone 1, Fascicolo 1: Relazioni e documentazioni relative all'attività e alla natura dell'ICl e alla situazione dell'industria cotoniera, 1932-4-1948, sottofasc. Deliberazioni obbligatorie].

IMI, Memorandum on Saici by Emilio Papasogli, 1st July 1952 in Intesa Sanpaolo Bank historical archives, Rome [ASI-IMI, Carte Siglienti S-BEI 25,'Relazione tecnica sulla SAICl, Milano-Torviscosa del Dr Emilio Papasogli, 1 luglio 1952'] 
IMI, 'Report on textile industry, June-September 1952' in Intesa Sanpaolo Bank Historical archives, Rome, [ASI-IMI, Verbali del Comitato Esecutivo, P_24, Relazione sull'industria tessile, giugno- settembre 1952]

IMI, Note from Enrico Murri, 16 September 1952 in Intesa Sanpaolo Bank historical archives, Rome [ASI-IMI, Servizio Ispettorato, Gestione Ordinaria, IMI ISP 68, 'Nota dell'Ing. Enrico Murri del 16 settembre 1952']

IMI, 'Deliberation of IMI's Executive Committee on SAICI's demand for a mortgage loan, 17 July 1956' in Intesa Sanpaolo Bank historical archives, Rome [ASI-IMI, Servizio Ispettorato, Gestione Ordinaria, b. 90, pratica 8167, 'Delibera del Comitato Esecutivo sulla domanda di mutuo della Saici, 17 luglio 1956'].

IMI, Note on SAICI, 17 July 1957 in Intesa Sanpaolo Bank historical archives, Rome [ASI-IMI, Servizio Ispettorato, Gestione Ordinaria, Pratica 8167, IMI ISP 90 'Comitato Esecutivo IMI, 'Nota riassuntiva e proposta in merito alla domanda di finanziamento per lire 2.000 milioni presentata dalla Saici' 17 luglio 1957]

IMI, Report on SAICI, July 1964 in Intesa Sanpaolo Bank historical archives, Rome [ASI-IMI, Gestione Ordinaria, Pratica 8167, IMI ISP 90 ‘Relazione su SAICI, luglio 1964']

IMI, 'Description of SAICI's patrimony, 5 December 1964' in Intesa Sanpaolo Bank Historical archives, Rome [ASI-IMI, Serie Mutui, pratica 13652 (.1) ORD, $\mathrm{SAICl}$ carte della segreteria, 'Descrizione dei beni nel contratto di mutuo del 5 dicembre 1964 (pratica 6567)']

Imperial (Commonwealth) Economic Committee, Industrial Fibres, (London, 1936, 1937,1938,1939, 1951)

Geoffrey Jones, 'Courtaulds in Continental Europe' in British multinationals: origins, management, performance (Aldershot-Brookfield, 1986), pp.119-39

Nicholas Kaldor, Strategic Factors in Economic Development (New York, 1967) R.P. Kerr, Committee of Imperial Defence, Supply Committee n.1, to the Board of Trade Supply Organisation, 17 October 1930 in National Archives, SUPP 3/34 Roberto Maiocchi, Gli scienziati del Duce. Il ruolo dei ricercatori e del CNR nella politica autarchica del fascismo (Rome, 2003)

Franco Marinotti, 'L'industria italiana dei tessili artificiali' in Luigi Lojacono, L'indipendenza economica italiana (Milano, 1937), pp.273-7 
C. Maters to John Hanbury-Williams, 24 January 1936' in V. Cerretano, 'The European rayon industry and the de-globalisation of the world economy' (PhD Thesis, Cambridge, 2003), p. 209

Mariana Mazzucato, The entrepreneurial state. Debunking public vs private sector myths (London, 2018)

Aristide Mauro, L'Istituto Cotoniero Italiano (Milano, 1944), pp.41-2 also in Archives of Fiom-CGIL, Milan [Archivio del Lavoro, Milano, Fondo Raitano, Faldone 2, Fascicolo 9: Opuscoli dell'ICl, 1939-44]

Alan Milward, War, economy and society, 1939-45 (Harmondsworth, 1977) Ministero per la Costituente, Rapporto della Commissione Economica presentato all'Assemblea Costituente. II. Industria. I. Relazione (2vols) (Rome, 1947)

Ministry of corporations to the director of the Bank of Italy, 10 March 1938 [Lettera del Ministero delle Corporazioni al Direttore della Banca d'Italia, 10 marzo 1938] in ASBI, Roma, Banca d'Italia, Direttorio Azzolini, cart 86, fasc 1 , pp.2-6.

Ministries Committee, minutes of 12 December 1935 in archives of the Bank of Italy [ 'Verbale del comitato interministeriale tenutosi presso il Ministero delle Finanze, 12 dicembre 1935'] in ASBI, Banca d'Italia, Direttorio Azzolini, cart 86, fasc 1, pp.518-20]

Ministry of Corporations, 'Report on autarkic plans', November 1937 [Ministero delle Corporazioni. Segretariato Generale del Consiglio Nazionale delle Corporazioni, Relazione riassuntiva piani autarchici al Comitato Corporativo Centrale, Novembre 1937] in ASIRI-I.R.I.'s Historical Archives [ASIRI - Archivio Storico Istituto per la Ricostruzione Industriale (IRI)], AU.1.6.18.2 in MAAS CCR.it/asirihap3/HapConsole.aspx

Giorgio Mortara, Prospettive economiche (Citta' di Castello, 1924-33)

David Mowery and Nathan Rosemberg, 'The influence of market demand upon innovation: a critical review of some empirical studies' Research Policy, 8 (2, 1979), pp.102-53

Official balance sheets and the financial reports of SAICI, various years, in Archives of Banca Intesa San Paolo, COMIT, Milan [Banca Comit, Intesa San Paolo (ASI BCI), Milan, Fondo US, 1 - cessate; cart.1, fasc.23: Sa Agricola per la Produzione Italiana di Cellulosa] various years

Andrea Ostuni, 'La cellulosa italiana. Promozione privata e intervento statale attraverso le iniziative della famiglia Pomilio, 1917-1963', Laurea dissertation, 
University of Pisa, a.y. 2015-6 [Tesi di laurea magistrale, Dipartimento di Civilta' e forme del sapere, Corso di laurea magistrale in Storia, Universita' di Pisa, a.a. 2015-6]

Andrea Ostuni, 'La Celdit di Chieti tra autarchia e miracolo economico' in Proposte e Ricerche, XLI, 80 (2018), pp.39-60

Emilio Papasogli, 'Report on SAICI, 1 July 1952' in Intesa Sanpaolo Bank Historical archives [ASI-IMI, Serie Mutui, Pratica 6567.1, 'Relazione tecnica sulla Saici, Milano-Torviscosa, del dr Emilio Papasogli, 1 luglio 1952'] Andrea Pellegrini, Cellulosa e carta in Italia (Roma, 1951), p. 43

Rolf Petri, Storia economica d'Italia. Dalla Grande guerra al miracolo economico (1918-1963) (Bologna, 2002)

Karl Polanyi, The Great Transformation (New York, 1945)

Ernesto Rossi, I padroni del vapore (Roma-Bari, 1966)

Report on autarky to Thaon de Revel, October 1936 in Thaon De Revel Archives, Fondazione Luigi Einaudi, Turin ['Proposte realizzazione autarchia. Situazione materie prime in Italia: cellulosa, cellulosa nitrabile, rayon, cloro' Roma, ottobre 1936, dattiloscritto, c.86, pp.83; in Fondazione Luigi Einaudi, Archivio Thaon de Revel, busta n.27.6.127]

Ricerche \& Studi SpA, 'Analisi di societa'. Societa' Nazionale Industria Applicazioni Viscosa- SNIA Viscosa, Milan, November 1971 held in the headquarters of Mediobanca, Milan

SAICI, Minutes of Meetings of the Board of Directors [Verbali Consiglio di Amministrazione della Saici, 19 June 1946, 2 April 1957, 27 June 1957, 4 June 1958] in http://www.cid-torviscosa.it/archivi/fondi-conservati/

Saici, Torviscosa (Torviscosa, 1949)

Saici, Torviscosa (Torviscosa, 1961)

Samuel Salvage (AVC), Cable to John Hanbury-Williams, 9 June 1937 in V.

Cerretano, 'The European rayon industry and the de-globalisation of the world economy' (PhD Thesis, Cambridge, 2003), p. 209

Pasquale Saraceno, Intervista sulla ricostruzione (Rome-Bari, 1977)

Jacob Schmookler, 'Economic sources of inventive activity', Journal of Economic History, 22 (1,1962), pp. 1-20

Jacob Schmookler, Invention and Economic Growth, (Cambridge, MA, 1966) 
Jonas Scherner, 'The beginnings of Nazi autarky policy: the 'National Pulp Programme' and the origin of regional staple fibre plants,' Economic History Review, 61 (4,2008), pp.867-895

Marcella Spadoni, Il gruppo snia dal 1917 and 1951 (Torino, 2003)

Snia Viscosa, Gruppo Snia Viscosa (Milan, 1949);

Snia Viscosa's funding request to IMI, 10 April 1964 in Intesa Sanpaolo Bank Historical archives, Rome[ASI-IMI, Serie Mutui, pratica 13652 (.1) ORD, SAICI carte della segreteria, 'Domanda di finanziamento della Snia Viscosa all'IMI del 10 aprile $\left.1964^{\prime}\right]$

Snia Viscosa, Minutes of Board of Directors [Verbale del Consiglio di Amministrazione della Snia Viscosa], 2 marzo 1936 in http://www.cidtorviscosa.it/archivi/fondi-conservati/

Textile Organon, (New York, Statistical Base Book, January 1962), p.18;

US Tariff Commission, The Rayon Industry (Washington, 1944)

Vera Zamagni, Come perdere la guerra e vincere la pace. L'economia italiana tra guerra e opoguerra, 1938-1947 (Bologna, 1997) 
TAB.1

Italy: output and consumption of cellulose in metric tons, 1926-1950

\begin{tabular}{|c|c|c|c|c|c|c|c|c|c|}
\hline & \multicolumn{3}{|c|}{ Domestic output (X) } & \multicolumn{3}{|c|}{ Domestic consumption $(\mathrm{Y})$} & \multicolumn{3}{|c|}{ Share of $X / Y$ in $\%$} \\
\hline & paper & fibres & total & carta & fibres & total & paper & fibres & total \\
\hline 1926 & 2,860 & - & 2,860 & 114,438 & 25,000 & 139,438 & 2.5 & - & 2.1 \\
\hline 1927 & 3,800 & - & 3,800 & 81,421 & 36,600 & 118,021 & 4.7 & - & 3.2 \\
\hline 1928 & 2,400 & - & 2,400 & 131,477 & 39,000 & 170,477 & 1.8 & - & 1.4 \\
\hline 1929 & 2,484 & - & 2,484 & 150,209 & 48,500 & 198,709 & 1.7 & - & 1.3 \\
\hline 1930 & 6,140 & - & 6,140 & 138,862 & 45,000 & 183,862 & 4.4 & - & 3.3 \\
\hline 1931 & 6,000 & - & 6,000 & 130,947 & 47,100 & 178,047 & 4.6 & - & 3.4 \\
\hline 1932 & 7,000 & - & 7,000 & 137,387 & 50,100 & 187,487 & 5.1 & - & 3.7 \\
\hline 1933 & 3,722 & - & 3,722 & 167,421 & 55,000 & 222,421 & 2.2 & - & 1.7 \\
\hline 1934 & 8,199 & - & 8,199 & 201,999 & 60,800 & 262,799 & 4.1 & - & 3.1 \\
\hline 1935 & 11,839 & - & 11,839 & 250,238 & 89,900 & 340,138 & 4.7 & - & 3.5 \\
\hline 1936 & 23,571 & - & 23,571 & 132,271 & 111,400 & 243,671 & 17.8 & - & 9.7 \\
\hline 1937 & 37,132 & - & 37,132 & 162,432 & 122,300 & 284,732 & 22.9 & - & 13.0 \\
\hline 1938 & 40,604 & 600 & 41,204 & 159,337 & 146,026 & 305,363 & 25.5 & 0.4 & 13.5 \\
\hline 1939 & 53,823 & 7,600 & 61,423 & 178,697 & 187,756 & 366,453 & 30.1 & 4.0 & 16.8 \\
\hline 1940 & 60,617 & 16,289 & 76,906 & 205,959 & 219,325 & 425,284 & 29.4 & 7.4 & 18.1 \\
\hline 1941 & 63,253 & 22,473 & 85,726 & 194,613 & 198,444 & 393,057 & 32.5 & 11.3 & 21.8 \\
\hline 1942 & 43,400 & 17,800 & 61,200 & 179,912 & 160,220 & 340,132 & 24.1 & 11.1 & 18.0 \\
\hline 1946 & 31,360 & 38,600 & 69,960 & 78,619 & 106,840 & 185,459 & 39.9 & 36.1 & 37.7 \\
\hline 1947 & 45,156 & 15,980 & 61,136 & 130,926 & 105,770 & 236,696 & 34.5 & 15.1 & 25.8 \\
\hline 1948 & 66,627 & 32,930 & 99,557 & 123,883 & 68,041 & 191,924 & 53.8 & 48.4 & 51.9 \\
\hline 1949 & 69,221 & 43,390 & 112,611 & 182,380 & 107,525 & 289,905 & 38.0 & 40.4 & 38.8 \\
\hline 1950 & 87,867 & 43,673 & 131,540 & 227,828 & 99,946 & 327,774 & 38.6 & 43.7 & 40.1 \\
\hline
\end{tabular}


TAB.2

Italy: Output, imports, exports and domestic consumption (output plus imports less exports) of rayon in thousand metric tons, 1923-1941

\begin{tabular}{|c|c|c|c|c|c|c|}
\hline & Output & Imports & Exports & Consumption & $\begin{array}{r}\text { Exports } \\
\text { as \% } \\
\text { of output }\end{array}$ & $\begin{array}{r}\text { Imports } \\
\text { as \% } \\
\text { of output }\end{array}$ \\
\hline 1923 & 5.0 & 0.5 & 2.4 & 3.1 & 48.0 & 10.0 \\
\hline 1924 & 10.5 & 0.6 & 4.7 & 6.4 & 44.8 & 5.7 \\
\hline 1925 & 14.0 & 0.6 & 7.4 & 7.2 & 52.9 & 4.3 \\
\hline 1926 & 18.0 & 0.8 & 9.9 & 8.9 & 55.0 & 4.4 \\
\hline 1927 & 25.0 & 0.5 & 14.9 & 10.6 & 59.6 & 2.0 \\
\hline 1928 & 26.0 & 0.5 & 15.6 & 10.9 & 60.0 & 1.9 \\
\hline 1929 & 32.5 & 1.2 & 18.5 & 15.2 & 56.9 & 3.7 \\
\hline 1930 & 30.5 & 0.3 & 19.4 & 11.4 & 63.6 & 1.0 \\
\hline 1931 & 32.2 & 1.4 & 22.5 & 11.0 & 70.0 & 4.3 \\
\hline 1932 & 34.7 & 0.9 & 18.9 & 16.7 & 54.4 & 5.4 \\
\hline 1933 & 37.5 & 1.0 & 19.1 & 19.4 & 50.8 & 5.1 \\
\hline 1934 & 48.9 & 1.1 & 30.0 & 20.0 & 61.4 & 5.5 \\
\hline 1935 & 69.9 & 0.5 & 33.9 & 36.5 & 48.5 & 1.3 \\
\hline 1936 & 89.0 & 0.6 & 30.3 & 59.3 & 34.0 & 1.0 \\
\hline 1937 & 118.5 & 1.1 & 43.6 & 76.0 & 36.8 & 1.4 \\
\hline 1938 & 119.5 & 1.1 & 38.6 & 82.0 & 32.3 & 1.3 \\
\hline 1939 & 138.3 & na & na & na & na & na \\
\hline 1940 & 162.4 & 0.9 & 37.4 & 125.8 & 23.0 & 0.7 \\
\hline 1941 & 182.4 & 0.8 & 43.7 & 139.4 & 24.0 & 0.6 \\
\hline
\end{tabular}

Sources: (imports) Board of Trade, (London, 1928); Imperial Economic Committee, (London, 1936, 1937,1938,1939, 1951), Mortara, (Citta' di Castello, 1924-33); (output and exports), Textile Organon, (New York, Statistical Base Book, January 1962), p.18; Banca d'Italia (Rome, 1938), vol II, p.880 
TAB.3

Italy, Germany, Japan: shares of staple fibres' world output in thousand metric tons ( $Y$ ) and as percentage of global staple fibres output, 1929-41

\begin{tabular}{|c|c|c|c|c|c|c|c|}
\hline & \multicolumn{2}{|c|}{ Italy } & \multicolumn{2}{|c|}{ Germany } & \multicolumn{2}{|c|}{ Japan } & \multirow{2}{*}{$\begin{array}{l}\text { Staple } \\
\text { fibres as \% } \\
\text { of world } \\
\text { rayon } \\
\text { output }\end{array}$} \\
\hline & $\mathrm{Y}$ & $\%$ & Y & $\%$ & $\mathrm{Y}$ & $\%$ & \\
\hline 1929 & 0.8 & 22.2 & 1.1 & 30.6 & & & 1.8 \\
\hline 1930 & 0.3 & 9.4 & 2.0 & 62.5 & & & 1.5 \\
\hline 1931 & 0.6 & 14.6 & 2.0 & 48.8 & & & 1.8 \\
\hline 1932 & 4.3 & 52.4 & 1.4 & 17.1 & 0.3 & 3.7 & 3.4 \\
\hline 1933 & 5.0 & 36.8 & 4.0 & 29.4 & 0.5 & 3.7 & 4.3 \\
\hline 1934 & 10.0 & 40.8 & 7.2 & 29.4 & 2.1 & 8.6 & 6.6 \\
\hline 1935 & 31.0 & 47.8 & 17.2 & 26.5 & 6.2 & 9.6 & 13.3 \\
\hline 1936 & 49.9 & 36.3 & 43.0 & 31.3 & 20.8 & 15.1 & 22.9 \\
\hline 1937 & 71.0 & 24.4 & 106.3 & 36.5 & 79.6 & 27.3 & 34.9 \\
\hline 1938 & 73.5 & 17.2 & 160.7 & 37.7 & 148 & 34.8 & 48.5 \\
\hline 1939 & 83.4 & 16.7 & 204.6 & 40.9 & 137 & 27.3 & 49.2 \\
\hline 1940 & 109.0 & 18.6 & 240.1 & 41.0 & 130 & 22.2 & 51.9 \\
\hline 1941 & 124.7 & 17.7 & 292.6 & 41.4 & 135 & 19.0 & 55.3 \\
\hline
\end{tabular}

Source: Textile Organon, (New York, January 1962 and June 1966). 
TAB.4

Imports of cotton and wool in thousand metric tons $(\mathrm{Y})$ and in thousand lire of 1938 (Z), 1921-41

\begin{tabular}{|c|c|c|c|c|}
\hline & \multicolumn{2}{|c|}{ Cotton } & \multicolumn{2}{|c|}{ Wool } \\
\hline & Y & Z & $Y$ & Z \\
\hline 1921 & 157.9 & $1,947,710$ & 20.1 & 363,335 \\
\hline 1925 & 236.9 & $3,683,880$ & 34.9 & 902,218 \\
\hline 1928 & 232.5 & $2,201,495$ & 48.5 & 818,903 \\
\hline 1930 & 204.7 & $1,430,878$ & 54.2 & 508,595 \\
\hline 1931 & 170.5 & 691,140 & 47.6 & 284,608 \\
\hline 1932 & 190.2 & 642,962 & 72.1 & 315,236 \\
\hline 1933 & 219.8 & 688,915 & 85.9 & 347,867 \\
\hline 1934 & 187.4 & 561,777 & 66.8 & 364,372 \\
\hline 1935 & 148.7 & 455,763 & 52.6 & 214,178 \\
\hline 1936 & 101.4 & 381,874 & 19.2 & 124,331 \\
\hline 1937 & 166.4 & 980,731 & 42.2 & 503,518 \\
\hline 1938 & 158.5 & 827,723 & 35.0 & 379,201 \\
\hline 1939 & 110.7 & 579,693 & 30.1 & 276,198 \\
\hline 1940 & 107.3 & 771,588 & 22.1 & 306,823 \\
\hline 1941 & 4.5 & 45,469 & 2.8 & 59,864 \\
\hline 1942 & 1.8 & 20,629 & 0.8 & 45,565 \\
\hline
\end{tabular}

Sources: data from Federico et al. (2011, Table 9, pp. 239-40) and (lire 1938) www.istat.it/it/archivio/210867 


\section{TAB.5}

Snia Viscosa: output of yarns and staple fibres in thousand metric tons (Y) and as a share of total output, 1935-41

\begin{tabular}{|c|c|c|c|c|c|c|c|c|c|}
\hline & & & & & & & & \multicolumn{2}{|c|}{ Staple fibres as \% of } \\
\hline & \multicolumn{2}{|c|}{ Yarn } & \multicolumn{2}{|c|}{$\begin{array}{l}\text { Staple } \\
\text { fibres }\end{array}$} & $\begin{array}{r}\text { Protein } \\
\text { fibres }\end{array}$ & \multicolumn{2}{|c|}{$\begin{array}{l}\text { Total } \\
\text { output }\end{array}$} & $\begin{array}{l}\text { Italian } \\
\text { output }\end{array}$ & $\begin{array}{l}\text { world } \\
\text { output }\end{array}$ \\
\hline & $\mathrm{Y}$ & $\%$ & $\mathrm{Y}$ & $\%$ & $\mathrm{Y}$ & $\mathrm{Y}$ & $\%$ & $\%$ & $\%$ \\
\hline 1935 & 14.5 & 37.7 & 24.0 & 62.3 & & 38.5 & 100.0 & 77.4 & 7.9 \\
\hline 1936 & 15.5 & 31.1 & 34.0 & 68.1 & $\begin{array}{ll}0.3 & 0.8\end{array}$ & 49.9 & 100.0 & 68.1 & 8.3 \\
\hline 1937 & 21.7 & 32.1 & 44.3 & 65.5 & $\begin{array}{ll}1.6 & 3.2\end{array}$ & 67.6 & 100.0 & 62.4 & 8.1 \\
\hline 1938 & 18.7 & 27.5 & 47.5 & 70.0 & 1.72 .5 & 67.9 & 100.0 & 64.6 & 7.7 \\
\hline 1939 & 22.7 & 28.5 & 55.0 & 69.1 & 1.82 .7 & 79.6 & 100.0 & 65.9 & 7.8 \\
\hline 1940 & 20.5 & 22.2 & 74.2 & 80.4 & 3.64 .5 & 92.3 & 100.0 & 68.1 & 8.1 \\
\hline 1941 & 21.6 & 18.6 & 90.5 & 77.8 & 4.14 .4 & 116.3 & 100.0 & 72.6 & 9.0 \\
\hline
\end{tabular}

Source: output and exports, Allit (August 1945); Italian and world exports: Imperial (Commonwealth) Economic Committee (1937 and 1939); world and Italian rayon output: Textile Organon (January 1962,p.18) 
TAB.6

Snia Viscosa: production capacity by spinning nozzles in 1940 and in 1945

\begin{tabular}{|c|c|c|c|c|c|c|c|}
\hline & & \multicolumn{3}{|c|}{1940} & \multicolumn{3}{|c|}{1945} \\
\hline & & yarns & staple fibres & total & yarns & staple fibres & total \\
\hline \multicolumn{8}{|l|}{ Snia Viscosa } \\
\hline & Cesano & 12,344 & 2,570 & 14,914 & 12,344 & 2,570 & 14,914 \\
\hline & Pavia & 11,994 & 1,352 & 13,346 & 11,994 & 1,352 & 13,346 \\
\hline & Varedo & 4,800 & 2,600 & 7,400 & 4,800 & 2,600 & 7,400 \\
\hline & Magenta & 7,080 & - & 7,080 & 7,080 & - & \\
\hline & Abbadia & 8,000 & 4,080 & 12,080 & 8,000 & 4,080 & 12,080 \\
\hline & Vanaria & 12,960 & 1,870 & 14,830 & 12,960 & 1,870 & 14,830 \\
\hline & Total & 57,178 & 12,472 & 69,650 & 57,178 & 12,472 & 69,650 \\
\hline \multicolumn{8}{|l|}{ Cisa Group } \\
\hline & Padua & 7,017 & 300 & 7,317 & 7,017 & 300 & 7,317 \\
\hline & Rome & 10,600 & 400 & 11,000 & 7,800 & 400 & 8,200 \\
\hline & Naples & - & 1,900 & 1,900 & - & - & \\
\hline & Rieti & 9,000 & 700 & 9,700 & 9,000 & 700 & 9,700 \\
\hline & Total & 26,617 & 3,300 & 29,917 & 23,817 & 1,400 & 25,217 \\
\hline Grand Total & & 83,795 & 15,772 & 99,567 & 80,995 & 13,872 & 94,867 \\
\hline
\end{tabular}

Source: Allit (August 1945) 
TAB. 7

Snia Viscosa: holdings, profits, dividends, depreciation and capital, 1935-41

(million current lire)

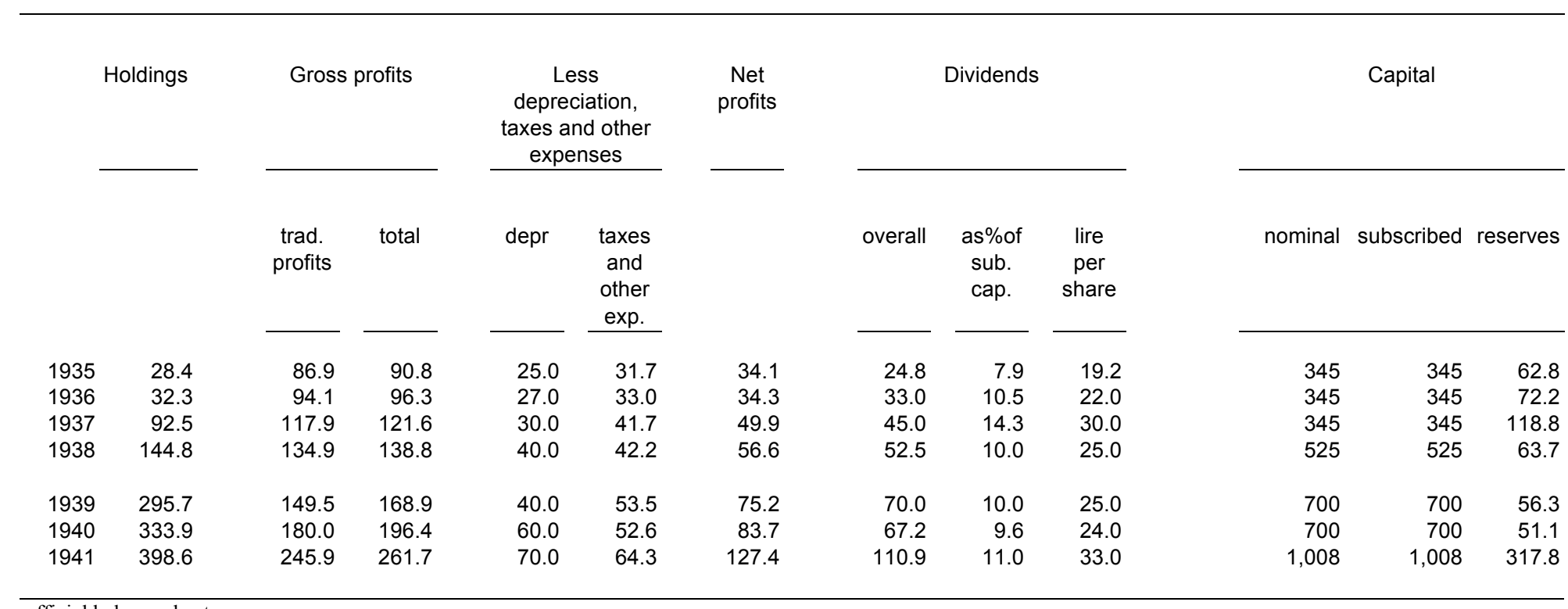

Source: official balance sheets 
TAB. 8

Snia Viscosa: Invested capital and its sources, 1935-41

(million current lire)

\begin{tabular}{|c|c|c|c|c|c|c|c|c|c|}
\hline \multirow{3}{*}{ Invested capit } & 1935 & 1936 & 1937 & 1938 & 1939 & 1940 & 1941 & \multirow{3}{*}{\multicolumn{2}{|c|}{ Yearly average }} \\
\hline & & & & & & & & & \\
\hline & \multirow[b]{2}{*}{282.2} & \multirow[b]{2}{*}{$200 ?$} & \multirow[b]{2}{*}{2} & \multirow[b]{2}{*}{5250} & \multirow[b]{2}{*}{5} & \multirow[b]{2}{*}{5630} & \multirow[b]{2}{*}{1.002 .80} & & \\
\hline Works & & & & & & & & 505.2 & 46.1 \\
\hline Materials* & 135.2 & 179.2 & 208.0 & 234.7 & 268.2 & 289.6 & 312.4 & 232.5 & 21.2 \\
\hline Holdings & 28.4 & 32.2 & 92.5 & 144.8 & 295.7 & 333.9 & 398.5 & 189.4 & 17.3 \\
\hline Cash reserves & 147.3 & 132.3 & 124.4 & 102.1 & 141.7 & 159.0 & 374.9 & 168.8 & 15.4 \\
\hline Total & 593.1 & 643.0 & 740.5 & $1,006.6$ & $1,253.6$ & $1,345.5$ & $2,088.3$ & $1,095.8$ & 100.0 \\
\hline
\end{tabular}

\section{Source of capital}

\begin{tabular}{|c|c|c|c|c|c|c|c|c|c|}
\hline \multirow[b]{3}{*}{ Capital } & \multirow[b]{3}{*}{345.0} & \multirow[b]{3}{*}{345.0} & \multirow[b]{3}{*}{345.0} & \multirow[b]{3}{*}{525.0} & \multirow[b]{3}{*}{700.0} & \multirow[b]{3}{*}{700.0} & \multirow[b]{3}{*}{1008.0} & \multicolumn{2}{|c|}{ Yearly average } \\
\hline & & & & & & & & & $\%$ \\
\hline & & & & & & & & 566.9 & 51.7 \\
\hline Reserves\&Funds & 212.4 & 250.4 & 342.5 & 413.7 & 467.7 & 529.3 & 956.7 & 453.2 & 41.4 \\
\hline Banks\&Companies & 35.7 & 47.6 & 53.0 & 67.9 & 85.9 & 116.2 & 123.6 & 75.7 & 6.9 \\
\hline Total & 593.1 & 643 & 740.5 & $1,006.6$ & $1,253.6$ & $1,345.5$ & $2,088.3$ & $1,095.8$ & 100.0 \\
\hline
\end{tabular}

*Buffering stocks, customers, credits to companies of the group

Source: Official balance sheets 
TAB.9

SAICI: production and production costs compared to Norwegian prices, 1939-44

(migliaia di tonnellate and lire/kg)

\begin{tabular}{|c|c|c|c|c|c|c|c|c|}
\hline & \multicolumn{2}{|c|}{ Reeds } & \multicolumn{2}{|c|}{ Beech } & \multicolumn{2}{|c|}{ Fir } & \multirow{2}{*}{$\begin{array}{l}\text { Total } \\
\text { th.ton. }\end{array}$} & \multirow{2}{*}{$\begin{array}{c}\text { Norway prices } \\
\text { L/kg }\end{array}$} \\
\hline & th.ton. & $\mathrm{L} / \mathrm{kg}$ & th.ton. & $\mathrm{L} / \mathrm{kg}$ & th.ton. & $\mathrm{L} / \mathrm{kg}$ & & \\
\hline 1939 & 2.5 & 1.6 & 1.7 & 1.4 & na & na & 4.2 & 1.5 \\
\hline 1940 & na & na & 15.4 & 2.3 & na & na & 15.4 & 2 \\
\hline 1941 & 2.1 & 3.2 & 17.9 & 2.4 & 4.7 & 3.3 & 24.9 & 2.4 \\
\hline 1942 & 5.2 & 4.6 & 0.9 & 3.5 & 6 & 4.3 & 12.2 & 3.4 \\
\hline 1943 & 0.6 & 8.7 & nd & 6.2 & 2.6 & 5.5 & 3.3 & 3.5 \\
\hline 1944 & 3.7 & 10.2 & nd & 6.6 & 0.1 & 6.1 & 3.9 & na \\
\hline
\end{tabular}

Source: Allit (August 1945) 
TAB.10

SAICI: sources of cellulose production , 1947-56

\begin{tabular}{lccrrrr}
\hline & \multicolumn{2}{c}{1947} & \multicolumn{1}{c}{1956} & & \multicolumn{2}{c}{1959} \\
& M. tons & $\%$ & & $\%$ & & $\%$ \\
Reeds & 5,507 & 28.2 & 4,600 & 7.4 & 3,500 & 4.4 \\
Beech & 13,910 & 71.3 & & & & \\
Poplar & 133 & 0.7 & & & & \\
Eucaliptus & & & 57,600 & 92.6 & $* 55,100$ & 69.8 \\
Fir & & & & & 9,400 & 11.9 \\
Tot. & 19,500 & 100 & 62,200 & 100 & $* * 78,900$ & 100 \\
\hline
\end{tabular}

*include i faggi; **include 10,9 mila tonnellate di cellulosa per carta

Source: Minutes of SAICI Board Meetings, 16 July 1948, 2 April 1957, 14 May 1960. 
TAB.11

Saici: area in hectares of the agricultural estate, June 1946

\begin{tabular}{lr}
\hline Reeds & 1740 \\
Grain and other & 2339 \\
Rented to third parties & 439 \\
As yet to be cultivated & 545 \\
Uncultivable & 276 \\
\hline Other & 363 \\
Total & 5665 \\
\hline
\end{tabular}

Source: Minutes of SAICI Board Meetings, 19 June 1946 
TAB.12

Saici: output of cellulose and associated chemicals, 1953-6

\begin{tabular}{lrrrrrrr}
\hline & 1953 & 1954 & 1955 & 1956 & 1961 & 1962 & 1963 \\
\cline { 2 - 8 } Cellulose & 47,713 & 38,300 & 59,592 & 66,582 & 90,164 & 93,275 & 92,830 \\
Alcohol (quintals of pure alcohol) & 8,577 & 10,026 & 7,169 & 8,554 & & & \\
Sodic lye and soda (from 1961) & 4,228 & 4,685 & 6,438 & 5,872 & 18,024 & 22,169 & 29,280 \\
Chlorine & 3,746 & 4,152 & 5,704 & 5,203 & 12,304 & 16,231 & 21,977 \\
Cloridric acid 33 percent & 1,539 & 2,201 & 2,582 & 2,321 & 2,919 & 3,722 & 4,697 \\
Sodium hypochlorite & 5,447 & 10,974 & 10,943 & 9,240 & 25,226 & 21,943 & 24,133 \\
Electricity in GWh & 43.2 & 71.3 & 108.5 & 86.5 & 99.26 & 88.52 & 102.00 \\
\hline
\end{tabular}

Source: IMI (17 July 1957 and July 1964) 
TAB 13

Saici and Snia Viscosa: workforce $(\mathrm{X})$, cellulose output in metric tons $(\mathrm{Y})$ and yearly output per unit $(\mathrm{X} / \mathrm{Y}), 1942-70$

\begin{tabular}{|c|c|c|c|c|}
\hline & \multicolumn{3}{|c|}{ SAICI } & \multirow{2}{*}{$\frac{{ }^{*} \text { Snia Viscosa }}{\mathrm{X}}$} \\
\hline & $x$ & $Y$ & $X / Y$ & \\
\hline 1942 & 5,009 & 12,309 & 2.5 & \\
\hline 1947 & & & & 27,361 \\
\hline 1948 & 3,173 & 36,685 & 11.5 & na \\
\hline 1951 & 3,011 & 52,498 & 17.4 & 16,000 \\
\hline 1961 & 1,848 & 90,164 & 48.8 & 21,000 \\
\hline 1963 & 1,965 & 92,830 & 47.2 & na \\
\hline 1965 & & & & 14,242 \\
\hline 1967 & & & & 12,974 \\
\hline 1969 & & & & 22,121 \\
\hline 1970 & & & & 24,939 \\
\hline
\end{tabular}

*only chemical fibres plants.

Source: (Saici) IMI (1st July 1952 and 16 September 1952); (Snia Viscosa) Ricerche e Studi (November, 1971) 
TAB.14

Snia Viscosa: consumption of cellulose and associated chemicals produced by Saici in 1970

\begin{tabular}{lrr}
\hline & Output & Consumption \\
& Tons & $\%$ \\
\hline Cellulose & 105,000 & 60 \\
Semichimical wood-pulp & 30,000 & 15 \\
Caprolactam & 15,000 & 100 \\
Ammonium sulphate & 65,000 & 30 \\
Chlorine-soda & 120,000 & 65 \\
Sulphuric acid & 90,000 & 100 \\
Ftalic anhydride & 12,000 & 100 \\
Maleic anhydrid & 5,000 & 20 \\
\hline
\end{tabular}

Source: Ricerche e Studi (November, 1971) 
TAB 15

Italy: consumption by firm of cellulose for rayon, 1951 (thousand metric tonnes)

$\begin{array}{lcc}\text { Snia Viscosa } & 84 \\ \text { Casale } & 14 \\ \text { Chatillon } & 7,5 \\ \text { Gerli } & 4,8 \\ \text { Orsi Mangelli } & 5,3 \\ \text { Pirelli } & 0,9 \\ \text { Acetato Chatillon } & 2,2 \\ \text { Acetato Rodiaceta } & 1,8 \\ \text { Bemberg } & 122 \\ \text { Total } & 70 \\ \text { Imported } & 52\end{array}$

Source: IMI (1st July 1952) 
TAB.16

Saici: increases in capital in thousand million current lire, 1938-1968

\begin{tabular}{rrr}
\hline & From & To \\
\hline 1938 & 50 & 100 \\
1941 & 150 & 200 \\
1949 & 200 & 2,000 \\
1960 & 2,000 & 5,000 \\
1961 & 5,000 & 10,000 \\
1965 & 10,000 & 15,000 \\
$* 1968$ & 15,000 & 56,000
\end{tabular}

*merged into Snia BDP

Source: Official balance sheets 